\title{
POPULISM AND TECHNOCRACY: OPPOSITES OR COMPLEMENTS?
}

\author{
Christopher Bickerton (University of Cambridge) \\ Carlo Invernizzi Accetti (Université Libre de Bruxelles/Sciences Po Paris)
}

\begin{abstract}
Whilst populism and technocracy are increasingly appearing as the two organizing poles of contemporary politics in western democracies, the exact nature of their relationship has not been the focus of systematic attention. In this paper, we argue that whilst these two terms - and the political realities they refer to - are usually as assumed to be irreducibly opposed to one another, there is also an important element of complementarity between them. This complementarity consists in the fact that both populism and technocracy are predicated on an implicit critique of a specific political form, which we refer to here as 'party democracy', defining it as a political regime based on two key features: the mediation of political conflicts through the institution of political parties; and a procedural conception of political legitimacy according to which political outcomes are legitimate just to the extent that they are the product of a set of democratic procedures revolving around the principles of parliamentary deliberation and electoral competition. In order to advance this argument, we rely on a close analysis of works by Ernesto Laclau and Pierre Rosanvallon as exemplary manifestations of the contemporary cases for populism and technocracy respectively.
\end{abstract}




\section{INTRODUCTION}

Two salient features of contemporary politics in Western democracies are increasingly capturing public attention. On one hand, we observe a growing concentration of power in the hands of a set of unelected 'regulatory bodies', drawing their legitimacy primarily from their technical competence and administrative expertise (Majone 1996; Scharpf 1999; Fischer 2009; Valbruzzi and McDonnell 2013). On the other hand, we see the emergence and widespread success of a variety of so-called 'populist' movements and parties, appealing directly to 'the people' in order to mobilize opposition against established institutions and elites (Canovan 1999; Mudde 2004; Taggart 2000; Arditi 2005; Albertazzi and McDonnell 2008; Muller 2013; Urbinati 2014).

Both these developments challenge the pertinence of the 'Left/Right' distinction as the principal axis of political confrontation. In the last round of European elections, for instance, much of Marine Le Pen's campaign in France was run on the idea that her party is 'neither leftnor right- wing' (" $n i$ de droite ni de gauche") but rather interested in reasserting the values of 'popular sovereignty' and 'national self-determination' against what she routinely refers to as the 'European technocracy' (Le Pen 2012). Beppe Grillo in Italy and the Podemos movement in Spain have similarly gained widespread support by advancing the idea that the traditional Left/Right distinction is obsolete and ought to be replaced by a new structuring opposition between the 'people' and 'la casta' (Grillo and Casaleggio 2011; Iglesias and Rivero 2014).

Mirroring their populist opponents, so-called 'technocrats' have been eager to present themselves as non-partisan and committed to providing 'pragmatic' solutions to political problems. In a book published in 2012, the former Italian Prime Minister, Mario Monti, and a current member of the European Parliament and former employee of the European Commission, Sylvie Goulard, presented the current crisis of European institutions as a consequence of the "short-termism" and "irresponsibility" of "populist" politics. The book concluded that "it is not through a demonization of expertise, but through a correct combination of technocracy and democracy that public policy can achieve a better temporal pertinence" (Monti and Goulard 2012). 
This conflict between populism and technocracy is also a reoccurring theme in the United States, with several commentators stating explicitly that it is progressively replacing the Left/Right distinction as the principal axis of political identification (e.g. Kenneally 2009; Freedland 2010; Williams 2011). Along similar lines, in the second volume of his latest book on Political Order and Political Decay, Francis Fukuyama has characterized the United States as a "state of courts and parties" where technocratic and populist elements are combined in destructive and dangerous ways (Fukuyama, 2014).

Whilst technocracy and populism are thus increasingly appearing as the two organizing poles of the contemporary political landscape, the exact nature of their relationship has not been the focus of much attention. The governing assumption underscoring much of the contemporary discourse is that these two notions are irreducibly opposed to each other. An obvious reason for this is that the terms are generally used negatively, as labels with which 'populist' figures excoriate their 'technocratic' opponents and vice versa. Beyond political invective, however, scholars and commentators have also treated these forms of discourse as being in direct conflict with one another. In an article taking stock of the multiple dimensions of the ongoing European crisis, Mark Leonard described populism and technocracy as "two contradictory and mutually reinforcing forces". "The EU", he wrote, "has been the ultimate technocratic project ... But, as the EU matured as a political project, its very success as a bureaucratic phenomenon fuelled a populist backlash at the national level" (Leonard 2011).

In an article focusing on the domestic dimensions of the European crisis, Claus Offe has talked about a "deep divorce" between "politics and policy" in Europe (2013: 610). In his view, we have on the one side "populist mass politics... that has no perceptible implication for policy making on citizens' core interests" and on the other side "there is elitist policy making that has no roots in... nor legitimation through politics" (2013: 610). This depiction is reminiscent of a distinction drawn by Vivienne Schmidt in her 2006 book, Democracy in Europe, where she identified a growing tension between populism understood as "politics without policy" and technocracy defined as "policy without politics" (Schmidt 2006).

The central argument we seek to advance in this paper is that beyond such evident dimensions of opposition between populism and technocracy, there is also an important element of complementarity between them, which so far has neither been studied nor thematized explicitly. This complementarity consists in the fact that both populist and technocratic forms of 
discourse are predicated on the critique of a specific political form, which we refer to as party democracy. Whilst this term has been taken up by scholars in a variety of ways, we define party democracy as a political regime based on two key features: the mediation of political conflicts through the institution of political parties; and the idea that the specific conception of the common good that ought to prevail and therefore be translated into public policy is the one that is constructed through the democratic procedures of parliamentary deliberation and electoral competition. ${ }^{1}$

This complementarity, we argue, should not be taken to mean that party democracy exists as an intermediary institutional form, sitting midway on a spectrum extending from populism at one end to technocracy at the other. Rather than being construed as some sort of compromise or mixture of populist and technocratic strains, we identify in this article a series of internal analytical commonalities between populist and technocratic discourses which explain why both posit party democracy as an object of critique. ${ }^{2}$ Our identification of a common critique of party democracy obviously raises the issue of this notion's normative desirability. For the purposes of this paper, however, we leave this dimension to one side. We focus instead on the purely analytical point that, despite their ostensible opposition, there is also a significant and hitherto unstudied degree of convergence between populism and technocracy consisting in their shared opposition to party democracy.

To substantiate this thesis, the paper is divided into three parts. In the first, we clarify the specific definition of party democracy we will be using by contextualizing it within a growing body of contemporary political theory literature that has sought to emphasize the normative significance of parties and partisanship within a democratic framework. In the second part, we focus on the notion of populism through an engagement with Ernesto Laclau's recent work on this topic. The aim of this part is to show that the normative appeal of populism depends on an implicit repudiation of the idea of party democracy. In the third part, we analyze Pierre Rosanvallon's recent work on democratic legitimacy and show that contemporary arguments for technocracy also rest upon a sustained critique of party democracy. In our selection of the works of Laclau and Rosanvallon, we believe we have identified two texts that are exemplary of broader tendencies within the field of contemporary political theory. By this, we do not of course refer to an idea of statistical or scientific sampling. Rather, we use the term 'exemplary'

\footnotetext{
${ }^{1}$ See, for instance, Manin, 1997, 206-218. For an extended and recent discussion, see Mair, 2014, 513-596.

${ }^{2}$ We thank one of the reviewers for helping us sharpen this particular point.
} 
in a sense closer to what Kant defines the notion of an example in his third Critique. There he explains that a particular case can "stand in" for a general logic, because it "illustrates" it in a paradigmatic fashion. ${ }^{3}$ In what follows, we accordingly do not aim to make an exhaustive analysis of all the texts employing the notions of populism or technocracy within the field of contemporary political theory. Rather, we focus on two authors whose texts usefully illustrate the way in which the notions of populism and technocracy are used and understood in contemporary theoretical discourse. Our discussion of Laclau and Rosnavallon is directed by our interest in what their respective views on populism and technocracy can tell us about the relationship between these two phenomena. We are thus aiming to provide a contextualized account of their ideas rather than to undertake any exhaustive exegesis of their work as a whole.

\section{I/ THE DEFINITION OF PARTY DEMOCRACY}

The term party democracy has typically been associated with the transition away from $19^{\text {th }}$ century parliamentarism as a consequence of the growing enfranchisement of European societies (Maier 1981; Manin 1997). As such, attention has been drawn towards the sociological roots and internal institutional dynamics of the term's main actors, the mass parties of the left and right (Duverger 1951; Lipset and Rokkan 1967). In this paper, we focus on what we consider to be the analytical core of party democracy, presenting it as a particular instantiation of a constitutive tension of democratic political life: the tension between particular interests on one hand, and an overarching idea of the common good on the other. In developing our account of party democracy, we draw on the burgeoning interest in parties from within the field of political philosophy and what this work has added to the interest in parties already manifest in political science. ${ }^{4}$

\footnotetext{
${ }^{3}$ For a fuller discussion of this way of understanding the notion of exemplarity see Ferrara 2008

${ }^{4}$ Though still very much neglected by political philosophers, political parties and partisanship have recently become the subject of a sustained and sophisticated interest on the part of some theorists (Bader and Bonotti, 2014; Bader, 2014; Goodin, 2008; Muirhead, 2006; Muirhead and Rosenblum, 2006; Rosenblum, 2008; White and Ypi, 2010a, 2010b; White, 2014). Whilst taking its inspiration for the above account of party democracy from this growing body of work, this paper puts less of an accent upon the subjective aspect of parties and partisanship. For example, Muirhead (2006) writes about the "party spirit" and stresses that what matters are not the unintended functions of party machines but rather the willed actions of partisans themselves (2006: 718). He also uses the language of "virtue", "sympathy" and stresses that partisanship is a behavioral disposition towards compromise and the need for "give and take" in a democracy (2006: 719). White and Ypi (2010a) are also interested in particular in what they call a "democratic ethos" and the role of parties in constructing this "positive conviction" among citizens regarding their abilities as political agents (2010a: 809). This paper's account of party democracy is more focused
} 
We define party democracy as a political regime based on two key features: the mediation of social conflict through the institution of the political party, understood as a means for the articulation of particular interests into comprehensive - although competing conceptions of the common good; and the idea that the specific conception of the common good that ought to prevail and therefore be translated into public policy is the one that is simultaneously constructed and identified through the democratic procedures of parliamentary deliberation and electoral competition, which is often but not always based on majority rule. Thus, schematically, we can say that party democracy is composed of two key analytical features: political mediation, and a procedural conception of political legitimacy.

The idea of political mediation refers to an issue that is at the heart of both empirical and theoretical accounts of political parties. In the work of Maurice Duverger, Eric Schattschneider and Giovanni Sartori, for instance, it is common to find metaphors that seek to express the manner in which parties translate societal cleavages into partisan positions able to mobilize electorates. Sartori used the term "transmission belt" (1976), while Duverger wrote of parties "crystallizing", "coagulating", "synthesizing" and "molding" social divisions (1954). More recently, Muirhead and Rosenblum have deployed the metaphor of the "bridge", arguing that parties do "unique political work" in a democracy by acting as "points of connection" between the political and non-political domains of social life (2006: 104). Matteo Bonotti also develops this point at length, dwelling on the "bilingualism" of political parties, meaning their ability to speak the languages of both civil associations and of state institutions (Bonotti, 2011: 20).

What recent political theoretical writing has stressed, however, is that parties also go beyond merely acting as "transmission belts" between society and the state. They also, as Muirhead and Rosenblum put it, "create the terms of contest" (2006: 103). Of course, they do not create divisions entirely ex nihilo. In constructing their partisan positions they rely upon existing divisions within society. However, an important function they also perform is that of integrating a plurality of particular interests and molding them into an overarching conception of the common good. This requires transforming the views and interests that isolated individuals or groups within society hold prior to being integrated in the political process. Political parties thus function as intermediary bodies between society and the state in the sense that they both

on its analytical features, identifying it as a particular institutional solution to the problem of the relation between whole and part in democratic political life. 
'reflect' social divisions present at the level of material and ideal interests, and 'constitute' them politically into competing visions of the common good.

This is implied by White and Ypi when they refer to parties as systems of "ideas-based cooperation between representatives across issues" (2010: 816), arguing that they play the role of "catalysts for political agency" by drawing links between disparate issues, and constituting them into normative representations of the common good. Relevant here is the language of the 'whole' and the 'parts'. From this perspective, party democracy represents not the disappearance of the tension between particular interests and the public good but rather its institutionalization at the level of political society. In contrast to Muirhead and Rosenblum, who argue that the "ethical partisan" will strive to "stand for the whole, well-ordered society", we suggest - as do White and Ypi - that party democracy is a regime based around the irreducible tension between the whole and the part, with parties standing for what Charles Maier refers to as the "legitimation of the partial good" (1981: 29).

The second key feature of party democracy is its procedural conception of political legitimacy. What this means is that the outputs of party democracy as a political regime are considered legitimate not because they approximate to some pre-political conception of 'truth' or 'justice', but rather because they are generated through a specific set of procedures that are taken to be expressive of the constitutive values of democracy i.e. freedom and equality, usually embodied in the principles of parliamentary deliberation and a set of decision-making rules. Originally developed as a theme by Hans Kelsen in his treaty on The Essence and Value of Democracy (2013), the same idea was taken up more recently by Nancy Rosenblum through her conceptualization of partisanship as a form of "regulated rivalry" (2008: 20). What Rosenblum's account adds to Kelsen's is a greater emphasis on the specific kind of ethos that this conception of "regulated rivalry" supposes. For her, this is an ethos based on the recognition of the 'partiality' of one's own conception of the good, and therefore on the willingness to search for compromise in political deliberation. Similarly, White and Ypi have also insisted on the "motivational" dimension of partisanship, arguing that while on one hand parties provide structures for political mobilization, on the other hand they serve to inscribe political engagement within a framework based on reciprocal respect and toleration (2010: 823). 
As was observed in particular by Richard Hofstadter in his historical account of the formation of the US party system (1969), all of the above implies that the concept of party democracy is inextricably tied to the idea of a "legitimate opposition", which is foreign to most other kinds of political regimes. Together with the concept of political mediation, this idea of proceduralism as involving recognition of the legitimacy of opposition will provide the basis for the ensuing analysis of populism and technocracy and their overlapping critique of the notion of party democracy.

\section{II/ FROM PARTISANSHIP TO HEGEMONY: ERNESTO LACLAU'S THEORY OF POPULISM}

Ernesto Laclau's theory of populism is given the most comprehensive treatment in his highly influential book On Populist Reason (2005). Much of the success of this text is due to the fact that Laclau is one of the few authors within the field of contemporary political theory (and science) who does not start from the assumption that populism must necessarily be seen as the symptom of a 'pathology' of existing democratic regimes. On the contrary, he attempts to show that the logic of populism is already engrained in the structural grammar of politics itself. For this reason, his ideas have often been referred to, and sometimes even been appropriated explicitly by, several 'really existing' populist movements both in Europe and elsewhere. ${ }^{5}$

For our purposes, we find from a close reading of Laclau's work that his normative defense of populism rests on a strong critique of both the idea of political mediation and a proceduralist conception of political legitimacy. What is noteworthy about Laclau, however, is that this critique is itself presented as a critique of technocracy and depoliticization. Laclau's elaboration of the alternative to populism and his critique of it is in fact so all-encompassing that it includes within it all those features we identify with the notion of party democracy.

The core of Laclau's theory of populism is the idea that it can be understood as a specific way of structuring the field of the political which displays three key characteristics. Firstly, the aggregation of a set of heterogeneous social grievances or "demands" through the establishment of a series of "equivalential links" between them. Secondly, the opposition of this

${ }^{5}$ On this point, see for instance Melenchon 2014 and Iglesias and Rivero 2014. 
aggregated set of demands to an "antagonistic pole" represented as the main reason for their lack of fulfillment. Thirdly, the crystallization of this antagonism by means of a "hegemonic logic" whereby one particular demand, or set of demands, is made to 'stand in' for the social whole. The overall result of these three operations is a structuring of the field of the political in terms of an overarching opposition between a hegemonic representation of the whole - for which the generic name is usually the 'people' - and an antagonistic other, usually represented as an oppressive and parasitic 'elite' (Laclau 2005: 117-120).

Laclau contrasts this way of structuring the political self-understanding of society with what he calls the "logic of difference". This consists in treating all individual social interests as separate "demands" addressed to the power that is taken to hold society together. The result is a conception of society as a "system for the solution of individual problems" which for Laclau can only be held together by a unified logic for dealing with them. Thus, for instance, he mentions the idea of "a society integrated entirely through the mechanisms of the welfare state" as "one in which only the differential logic would be accepted as a legitimate way of constructing the social" (2005: 78). He later adds that "the same can be said about 'neoliberalism', since it also presents itself as a panacea for a fissureless society - with the difference that in this case the trick is performed by the market, not by the state" (2005: 79).

Although Laclau presents these two alternative modes of structuring the social space i.e. the 'populist' division of society into a hegemonic representation of the people and its other, and the 'differential' integration of society with reference to a unifying logic for dealing with demands - as an analytical categorization, it is clear that he is not normatively indifferent between them. The basic reason is that Laclau shares with Carl Schmitt the assumption that there is something inherently valuable in the structuring the political space in terms of a dichotomous distinction between 'friends' and 'enemies' (Schmitt 1921). Thus, when Laclau asserts that the 'differential' integration of society in terms of a unifying logic such as that of the market or the welfare state amounts to a form of "depoliticization", this is clearly meant to function as a critique. Conversely, the claim that the logic of populism is structurally engrained in the very grammar of politics is meant to alert us to a very important function that populism is capable of carrying out. Much of Laclau's intellectual project, pursued jointly with Chantal Mouffe, has in fact consisted in arguing that the political Left should take up this insight and 
strategically deploy the concept of 'hegemony' as a way of counter-acting the depoliticizing tendencies of the welfare state and of the market (Laclau and Mouffe, 1985).

Taking Laclau's argument as a whole, we can therefore see it as a normative vindication of populism, based on the claim that populism is a way of preserving a sense of 'political antagonism' in the face of the multiple tendencies towards 'depoliticization' that Laclau takes to be implicit in the 'differential' logics of the market and the welfare state. We thus find in Laclau a version of the idea, outlined in the introduction above, that the contemporary political spectrum is founded upon an opposition between a hyper-politicized form of 'populism' and a depoliticized form of 'technocracy', where what is at stake is the preservation of the possibility of politics itself. ${ }^{6}$ The normative force of Laclau's theory of populism thus rests upon this dichotomous presentation of the political field, where populism is the only alternative to a depoliticized and technocratic realm. What counts as belonging to this realm is, however, extremely expansive and contains within it those two elements we identify as central to party democracy: political mediation and a procedural conception of political legitimacy.

With regards the first, Laclau very firmly rejects the concept of 'mediation' as a way of making sense of how political identities can be created out of a plurality of heterogeneous social demands. For him, the concept of mediation is inextricably tied to a "totalizing Hegelian metaphysics" according to which all forms of social conflict or division can be "rationally sublated" into a higher unity which at the same time overcomes them and preserves them (Laclau 2005: 93). As should already be clear from the outline provided above, however, the concept of mediation we have been referring to need not necessarily be tied to such a metaphysics. It is rather merely a way of indicating that as well as 'reflecting' underlying social cleavages, political parties also contribute in 'shaping' them, by molding a plurality of disparate social interests into a unified, although particular, conception of the common good.

\footnotetext{
${ }^{6}$ This is in fact the way in which Laclau appeared to understand his own argument. In a comment on his own theory published a few years after On Populist Reason, he explained that "political practices" operate "at diverse points of a continuum whose two reductio ad absurdum extremes would be a institutionalist discourse, dominated by a pure logic of difference, and a populist one, in which the logic of equivalence operates unchallenged". These two extremes, he felt, are "actually unreachable": "pure difference would mean a society so dominated by administration and by the individualization of social demands that no struggle around internal frontiers - i.e. no politics - would be possible; and pure equivalence would involve such a dissolution of social links that the very notion of 'social demand' would lose any meaning." (Laclau 2008: 45).
} 
What Laclau cannot take into account, owing to his rejection of the category of 'mediation', is the process whereby individual interests and demands can also be transformed by the logic through which they are integrated with one another - that is, in other words, what White and Ypi refer to as the 'normative' dimension of the process of construction of collective identities (White and Ypi 2010: 816). This is reflected in the fact that, for Laclau, the collective identity of the 'people' is created by establishing a series of "equivalential links" between individual social demands. By implication, what binds them together is ultimately only their common opposition to what he calls an "antagonistic pole" (i.e. the idea of an 'elite', or some kind of constitutive 'other').

This is the reason why Laclau is ultimately forced to recognize that even though populists aim at abolishing the specific social 'elite' against which they define themselves, in reality they cannot do without it because in absence of such an "antagonistic pole" the populist conception of the people would immediately dissolve into its constituent parts. Having rejected the idea of mediation, populism thus functions essentially as a way of lumping together a series of unreconstructed social antagonisms. The idea of party democracy we have developed above, on the other hand, is predicated on the idea that political identities can be constructed 'immanently' out of concrete social interests. This implies that they can subsist independently of each other, while at the same time recognizing their ineradicable partiality.

A second key element of tension between Laclau's theory of populism and the specific conception of party democracy we outlined above lies in the role played within the framework of the former by the concept of 'hegemony'. As we already pointed out, this is defined by Laclau as a process through which a particular social demand, or set of demands, succeeds in 'standing in' for a representation of the whole. This has the effect of portraying the political process as a zero-sum struggle between competing conceptions of the 'whole'. Within this framework, the concept of political deliberation in search for compromises with one's opponents' positions makes little sense. Hegemony, in short, is an all-or-nothing affair. In contrast, a key feature of the specific conception of party democracy we sought to outline above is that, while seeking to both articulate and defend a specific conception of the common good, the parties within it remain conscious of their partiality, and therefore open to the possibility of deliberating with their opponents and potentially also of integrating certain elements of their program into their own. 
This has consequences for the way in which political opposition is understood. In a context in which the key axis of political division is between a hegemonic conception of the 'whole' and an antagonistic 'part', the political struggle is bound to be tainted by a moral dimension where the latter ends up being represented as either morally evil or normatively illegitimate a priori (Cf. Muller 2013). Thus, paradoxically, even though Laclau's theory of populism was initially conceived as a way of preserving a sense of the significance of political antagonism, its ultimate consequence is to undermine the legitimacy of political opposition as such, because in the face of a hegemonic representation of the 'people' any form of political opposition or resistance is bound to be perceived as illegitimate.

A third element of tension between Laclau's theory of populism and the notion of party democracy concerns the relative degree of importance given to 'formal procedures', and in particular majority rule and individual rights. If there is no room for the mediation of social divisions, then a procedural account of political legitimacy becomes very difficult too. This is because such a procedural account rests upon the idea that political conflicts are stripped of any moral weight. 'Good' political outcomes cannot be known in advance but are rather subject to a contingent process of constant renegotiation with the parties involved. It is from this conception of legitimacy that the idea of a legitimate political opposition, discussed above, emerges. For political parties in party democracy, ttheir degree of legitimacy is not independent of the procedures themselves and it is ultimately dependent upon their ability to win votes.

In contrast to this, Laclau's own account of political opposition challenge the idea of there being any legitimacy in procedures themselves. Throughout Laclau's treatise on populism, the notions of 'majority rule' and 'individual rights' are almost never mentioned - except as a potential vector for the crystallization of a hegemonic identity, which for him is what happened on the occasion of the collapse of the Soviet regimes in Russia and Eastern Europe (when these ostensibly purely 'formal' concepts became the rallying points for the construction of a counterhegemonic protest movement against the existing regimes) (2005: 171).

What Laclau devotes much more space to is what he calls the "affective dimension" of the hegemonic logic whereby a specific part within the social system succeeds in 'standing in' for the whole (2005: 101). ${ }^{7}$ This is reminiscent of an idea we find in the work of Carl Schmitt,

\footnotetext{
${ }^{7}$ An entire section of his book is in fact dedicated to an analysis of the Lacanian theory of desire formation, through which Laclau argues that all desire is ultimately desire for a return to the original state of 'fullness' experienced in the mother's womb. On this basis, he contends that the performative 'success' of any hegemonic
} 
according to which the leader's capacity to 'embody' the unity of the people need not be validated through formal procedures, but can rather be "made palpable" through a process of “collective acclamation" (Schmitt 1923). Indeed, Schmitt goes as far as to suggest that the formal procedures of voting and majority rule are strictly speaking incompatible with the idea of popular sovereignty, because they have the effect of dissolving the people's unity at the very moment in which it is supposed to manifest itself (2005: 16).

Although Laclau does not explicitly endorse this rejection of majority rule, there appears to be nothing within the framework of his conception of populism which would in principle prevent it. Like Schmitt's idea of popular sovereignty, Laclau's conception of populism is predicated on a 'hegemonic' conception of political representation as 'embodiment'. Laclau's work on populism should therefore be understood as a struggle between two rival conceptions of political life. However, this struggle is not between populism versus technocracy, as he implies, but rather between his notion of populist politics and a very broad alternative that is characterized by mediated political divisions and by conceptions of legitimacy that are 'merely' procedural. In short, Laclau's defense of populism rests upon this posited conflict between populism and an alternative political space which can most accurately be described as party democracy.

\section{III/ TECHNOCRACY AGAINST PARTIES: PIERRE ROSANVALLON'S DEMOCRATIC}

\section{LEGITIMACY}

After having shown that Laclau's theory of populism is predicated on an implicit critique of party democracy, we now move on to argue something similar with respect to the notion of technocracy. For this purpose, we take Pierre Rosanvallon's book on Democratic Legitimacy, as our exemplary text (Rosanvallon 2011).

This choice may seem surprising given that this text is presented as a case for "enriching" the way in which the notion of democratic legitimacy is ordinarily understood, by complementing it with additional conceptual tools intended to ensure that political outcomes

claim to represent the social whole depends on its capacity to reactivate this original desire for 'fullness', while at the same time diverting it onto itself. For, as he puts it: "the desire to constitute a 'people' ... arises only when that original sense of fullness is experienced as lost, and partial objects within society (aims, figures, symbols) are so invested that they become the name of its absence" (Laclau 2005: 110-116). 
correspond to the common good. Indeed, the starting point of Rosanvallon's reasoning is the assumption that democratic legitimacy is based on the notion of "popular sovereignty" (2011: 59). However, what Rosanvallon also takes for granted is that the 'people' is an abstract entity, which never materializes concretely. ${ }^{8}$ From this he deduces that democratic regimes must rely on a plurality of different ways of representing it, combined in such a way that the interplay between them produces a more adequate representation of the common good than if only one such mechanism were employed (Rosanvallon 2011: 9-11).

The reason we maintain this can be read as an argument for technocracy is that amongst the various kinds of representative mechanisms that Rosanvallon discusses as means for obtaining a more adequate representation of the common good, there are at least two that he explicitly links to the notion of technocracy. The first is what Rosanvallon refers to as the "legitimacy of identification with generality", which corresponds to the idea of an independent bureaucracy as a separate pillar of democratic legitimacy, aside from electoral representation (2011: 33-39). Rosanvallon writes, for instance, that: "The neologism technocracy was coined [during the period of creation of independent bureaucracies] to denote a system of government in which experts organize and control the nation's resources for the good of all” (2011: 48).

The second 'technocratic' element of Rosanvallon's overall conception of democratic legitimacy is what he refers to as the "legitimacy of impartiality", linking it in particular to the recent proliferation of independent and non-elected regulatory bodies such as "independent central banks", "expert commissions" and "non-partisan authorities" (2011: 87-92). In the chapter devoted to the discussion of 'independent authorities', for instance, Rosanvallon concedes that for many of their early critics, these agencies "with their certainty of representing the public good against special interests, stood as symbols of technocratic and bureaucratic arrogance" (2011: 83).

To the extent that Rosanvallon's case for "enriching" the means of democratic representation involves defending the normative legitimacy of such institutions, we can say that he understands democracy not just as a form of government by the people, but also as government for the people. What is especially noteworthy about Rosanvallon's way of making this case is that he does not present it as an argument against the democratic idea of popular sovereignty but rather as a way of fulfilling it more effectively. The key difference with

\footnotetext{
${ }^{8}$ For a more detailed exposition of this point, see Rosanvallon 1998.
} 
ordinary theories of popular sovereignty, however, is that Rosanvallon does not understand the functional differentiation between different instances of popular representation as a 'hierarchical' distinction, which preserves the sense of a supremacy of the elected assembly, but rather as a 'horizontal' division of powers which are assumed to compete with each other by advancing different claims towards the representation of the same social whole. In this way, non-elected and 'technocratic' bodies such as independent bureaucracies and expert authorities effectively end up sharing sovereign power with elected representatives (2011: 10). It is worth noting that this very same argument is made by Giandomenico Majone in his account of the European Union, a 'technocratic' body par excellence. ${ }^{9}$

Another aspect of Rosanvallon's argument that is also very relevant to the argument of this paper is that, especially in his writings prior to the treatise on Democratic Legitimacy, Rosanvallon was keen to present the "complexity" that characterizes his conception of popular sovereignty in antithesis to - and indeed even an antidote against - the "simplification" that for him lies at the core of populism, itself assumed to consist in the idea that a unified and monolithic 'people' can be adequately represented by a single instance of political representation, whether that be a single individual, an elected assembly, or even a collective logic such as that of public demonstrations (Rosanvallon 2010). This suggests that, within the logic of Rosanvallon's thought, it is possible to find the same structuring opposition between 'technocracy' and 'populism' which we also found to be at the heart of Laclau's thought although the normative valence the two authors attach to these terms is reversed.

A closer reading of Rosanvallon's text on Democratic Legitimacy reveals that the main target of its critique is in reality not just populism, but a broader conception of democracy that

\footnotetext{
${ }^{9}$ In the context of Rousseau's original theorization of the notion of popular sovereignty, for instance, the 'executive' (i.e. what he calls the "government") is a "delegated" power, which accordingly remains subordinate to that of the popular assembly (Rousseau 1997). Within the framework of Rosanvallon's theory of democratic legitimacy, on the other hand, popular sovereignty is effectively relocated at the level of the interplay between several competing instances of popular representation. This explains why, towards the end of his treatise on Counter-Democracy Rosanvallon had already suggested that democratic theory should recover the classical republican ideal of a 'mixed constitution': “The idea of a mixed constitution - he write - arose in the Middle Ages in the course of the search for a regime that would combine the best features of aristocracy, democracy, and monarchy to create a polity as generous as it was rational. This idea is worth revisiting today, but with a somewhat different twist: democracy itself needs to be understood as a mixed regime, not as the result of a compromise between rival principles, such as liberty and equality, but rather as a composite of the three elements described above" (Rosanvallon 2008: 314). This attempt to revisie the older notion of the 'mixed constitution' and 'mixed government' is at the heart of Majone's work on the European Union as a regulatory state. Majone distinguishes between the model of the separation of powers based on the principle of popular sovereignty and a 'mixed government' model based upon the representation of interests. See Majone, 2005: 46-51.
} 
overlaps in many significant ways with the notion of party democracy as we have defined it. In fact, it is surprising to note that, after having been at the center of many of his previous reflections, the term 'populism' is mentioned only twice - and in passing - in Rosanvallon's book on Democratic Legitimacy. Far greater attention is instead devoted to the problems of majoritarian democracy, what he calls the "legitimacy of establishment" and what he claims is the bedrock of the way in which democratic legitimacy is ordinarily understood (Rosanvallon 2011: 17). In order to uncover what lies at the heart of Rosanvallon's case for technocracy it is therefore necessary to examine a little more closely how he understands this "legitimacy of establishment" and the reasons he finds it so problematic.

The key assumption at the core of what Rosanvallon calls the "legitimacy of establishment" is that "a majority vote establishes the legitimacy of government" (2011: 1). He finds this problematic because this idea relies on an "equivocal fiction": that the majority is somehow equivalent to the people as a whole. Referring to the reasoning employed by the Abbé de Sieyès to justify the principle of majority rule, Rosanvallon writes that: "If individuals are free and equal by nature, legitimate power can arise only from the unity of individual wills. But how are we to think of such unity? Sieyès resolved the problem by recourse to a fiction: the majority was said to be an equivalent of unanimity ... The problem was that Sieyès failed to make it clear whether this was a necessary legal fiction (whose consequences for the relation between law and politics remained to be spelled out) or a substantive equivalence" (2011: 24).

Employing language drawn from Laclau but reversing its normative valence, we can say that, for Rosanvallon, the majority principle rests on a 'hegemonic' logic, in that it arbitrarily assumes that a 'part' can stand in for the 'whole'. In contrast to Laclau, Rosanvallon takes this to be a weakness of majority rule. Thus, later he writes that "modern democratic regimes ... were fragile from the beginning", since "their establishment depended on a certain blindness as to their true nature" (2011: 31). This is also what underscores his further claim that the "legitimacy of establishment" needs to be "complemented" by other mechanisms for representing the people's will, which notably include the "legitimacy of identification with generality" and the "legitimacy of impartiality".

As we observed with respect to Laclau, this conception of democracy as an essentially 'hegemonic' project is itself predicated on a blindness to the two key features of party 
democracy. First of all, like Laclau, Rosanvallon assumes that majority rule is based on a logic of "equivalence" (i.e. the idea that the majority is equivalent to the whole). This ignores - and indeed excludes - the key function of political mediation played by political parties with the framework of really existing democratic regimes. What Rosanvallon does not seem to take into account in his characterization of the "legitimacy of establishment" is that when individuals vote in representative elections they do not usually express their preferences over a specific issue but rather manifest their support for one amongst various competing political projects, of which political parties are usually the vectors.

From this perspective, majoritarian elections can be seen as part of a broader process through which an overarching conception of the 'common good' is progressively extrapolated and defined out of the plurality of particular interests present within society (Kelsen 2013). Indeed, from the perspective of the specific conception of party democracy we sought to define above, this is a process that presupposes a prior process of political negotiation and articulation both within parties (to create collective - if partial - representations of the 'common good') and between them, usually resulting in 'compromise solutions', whose aim is to satisfy as many of the particular interests present within society as possible. By reducing the "legitimacy of establishment" to the idea of an "equivalence" between majority rule and popular sovereignty, Rosanvallon arbitrarily brushes aside the whole dimension of political mediation carried out by political parties within the framework of party democracy.

This is reflected in the way in which political parties are portrayed in Rosanvallon's book. Consistently, they appear as vectors for "special interests" and "particularistic concerns", thereby effectively eliding the conceptual difference between them and 'interest groups' or 'lobbies'. In the context of his discussion of the factors that led to the formation of independent bureaucracies as ways of compensating for the inherent deficiencies of the "legitimacy of establishment", for instance, Rosanvallon writes that: "political parties were instruments not for representing the public interest, but for enabling private interests to capture the public space" (2011: 37). Later, he also adds that this is why "at the end of the nineteenth century political parties came under attack everywhere", specifying that "these attacks were not solely a response to the parties' dysfunctions. They were also a natural product of a certain system of social representations" (2011: 30). 
The same overall conclusion also emerges if we consider the second key feature of party democracy i.e. the idea that political legitimacy is purely procedural in the sense that it emerges exclusively out of the way in which political decisions are taken and is not tied to any objective standard of political 'truth'. Due to the way in which Rosanvallon sets up his conception of democratic legitimacy - i.e. as a way of obtaining the most adequate possible representation of an elusive 'popular will' - he implicitly assumes that the basic criterion of political legitimacy is already given prior to and independently from the political process.

This is reflected in the fact that the fundamental critique he moves against the "legitimacy of establishment" is that it substitutes a "pragmatic selection procedure" (i.e. majoritarian elections) for a criterion of "substantive unanimity". At the very beginning of his chapter on this topic, Rosanvallon writes that: "Since democracy implies that each individual is the bearer of fundamental rights, the consent of all is the only incontestable guarantee of respect for each ... But the underlying requirement of unanimity is broader than this formulation implies. There is also a more anthropological interpretation of unanimity, in which unanimity symbolizes the organic wholeness of society ... Democratic regimes eventually adopted the principle of majority rule as a practical procedural necessity, since numerical unanimity was virtually impossible to achieve. Yet at the same time they remained under the sway of this older idea of substantive unanimity" (2011: 17, italics added).

This passage shows that Rosanvallon's conception of democratic legitimacy remains inscribed within the framework of an essentially Rousseauian conception of popular sovereignty, according to which the "general will" is an 'objective' reality, constructed out of the particular wills of the individuals concerned, but nonetheless assumed to exist prior to and independently from the political process itself. Hence, for Rosanvallon, democratic procedures are merely means for 'discovering' and 'approximating' a standard of political legitimacy that is assumed to precede them. The consequence is that the link between popular sovereignty and the formal procedures of majority rule is taken to be merely contingent rather than constitutive of the idea of democracy itself.

This is reflected in the admiration Rosanvallon displays for other ways of manifesting the "general will", beyond popular elections based on the principle of majority rule. Later in the same chapter on the "legitimacy of establishment" he writes that: "Popular assemblies were originally merely a way of testing and reaffirming the cohesion of the group", citing as 
examples the fact that: "in Rome, popular acclamation symbolized the consensus ideal" and that "similar rituals of unanimity existed elsewhere, in Germania and Gaul for instance" (Ibid: 18). Once again, this is reminiscent of Carl Schmitt's idea that individual voting based on the principle of majority rule may actually be incompatible with popular sovereignty, because it effectively dissolves the unity of the 'people' at the very moment in which it is supposed to be manifested. Rosanvallon, however, gives this reasoning a more 'technocratic' twist, since he goes on to argue that the "legitimacy of identification with generality" and the "legitimacy of impartiality" provide more adequate ways of approximating "substantive unanimity".

In the final analysis, Rosanvallon's apparent indifference and even disregard for the formal procedures of parliamentary democracy thus proves to be intimately connected with his essentially 'epistemic' conception of politics, according to which political process is ultimately way of discovering and implementing an objective 'truth' that precedes it. Once we accept the assumption that there exists an 'objective' and pre-political standard of political legitimacy, it seems difficult to resist the conclusion that some individuals are more competent than others in knowing what this standard requires, and should therefore be entrusted with the responsibility for ruling the others. ${ }^{10}$ Conversely, if we start from the assumption that the popular will can only be constructed through the political process itself, then it seems more difficult to argue for an exclusion of the people concerned from the process of determining it.

\section{CONCLUSION}

Our argument above has taken as its starting point the development of populist and technocratic forms of discourse within the political life of Western democracies. Whilst often

\footnotetext{
${ }^{10}$ Such a 'technocratic' twist to the idea of popular sovereignty was in fact prefigured by Rousseau himself. In the chapter of the Social Contract devoted to the equivocal figure of the 'Lawgiver', he writes that: 'By themselves, the people always will what is good, but they do not always discern it... They must accordingly be brought to see things as they are, and sometimes as they should be seen ... Hence the necessity of a Lawgiver", which is later described as an individual of "superior intelligence, who could understand the passions of men without feeling any of them, who had no affinity with our true nature but knew it to the full, whose happiness was independent of ours, but who would nonetheless make his happiness our concern" (Rousseau 1968: 83-84). In the light of what has been stated above it is perhaps not entirely out of place to read this passage as containing many of the same ideas that Rosanvallon would later develop with respect to the idea of a "legitimacy of identification with generality" and especially a "legitimacy of impartiality". Moreover, this would appear to be confirmed by the section of his book that Rosanvallon devotes to a reconstruction of the idea of an independent bureaucracy in France, which links it to a specific appropriation of the Republican ideal of popular sovereignty encapsulated in the notion of a class of "jacobins of excellence" (Rosanvallon 2011 pp. 38-43).
} 
associated with political developments in Western Europe, we have suggest that these forms of discourse are increasingly structuring the way we think about politics across the Western world. We noted that it is most common to suppose that populism and technocracy are related to one another, if at all, in the sense that one form of discourse is directly opposed to the other. The relationship is often framed as one of 'backlash' or of a 'reaction' of one against the other. Our suggestion has been that whilst points of contention and conflict obviously exist, there is also a strong element of complementarity between these two forms of discourse. More specifically, whilst 'populism' and 'technocracy' are often held to be used as negative labels that one throws as one's political opponents, we have found that what both forms of discourse are actually opposed to is not each other but the political regime of what we call party democracy. Before proceeding any further, we situated party democracy within the burgeoning literature in political theory on parties and partisanship. Taking our cue from the work of Muirhead, Rosenblum, White, Ypi and others, we defined party democracy in terms of two key features: the political mediation by parties of societal divisions; and a proceduralist conception of political legitimacy.

We substantiated this argument by critically analyzing two texts: Laclau's On Populist Reason and Rosanvallon's Democratic Legitimacy. Both texts were not strictly intended as texts that were representative of the way populism and technocracy are understood within political theory as a whole. Rather, they were taken as exemplary texts, meaning that they illustrated a particular logic or argument in an exceedingly clear and lucid way. In studying the two texts alongside one another, we found important parallels. Whilst Laclau defended populism against what he saw as the threat of increasingly depoliticized and technocratic forms of politics, the substance of what he was criticizing was not technocracy as such - which he conceded could never exist in a pure form anyway - but rather party democracy, and in particular its claim to providing political mediation and its arbitrary relationship to political truth. Similarly, Rosanvallon situated his defence of non-electoral forms of legitimacy as a response to the simplifying ways in which 'the people' had been equated with the majority since the French Revolution. Such simplification was not for Rosanvallon a problem of populism but rather was a pure product of the regime of party democracy. Whilst adopting normatively opposition positions, both Laclau and Rosanvallon were thus found to converge in their shared critique of party democracy. Investigating in detail this shared critique, we also found that Laclau and Rosanvallon both took issue specifically with the claims about political mediation and 
procedural rules found in the regimes of party democracy. By putting these two texts together and analyzing them on the basis of their complementarity, it becomes clear the ways in which populist and technocratic forms of discourse can be considered as two sides of the same coin, the coin being the critique of party democracy. Rosanvallon, for instance, is explicit in formulating a defence of technocracy that aims to take the side of the people against their political leaders and elite. This suggests that in public discourse, arguments about technocracy should not be associated only with an elitist disdain for the public; it is also possible to identify a more 'populist' defence of technocracy that draws on the themes identified at a more abstract level by Rosanvallon.

Many implications flow from this argument, not least the one that our understanding of the relationship between populism and technocracy should be substantially revised. At the same time, our argument about the commonality between populism and technocracy has important implications for the way in which we think about party democracy. Most notably, it suggests that the idea of contemporary political life being restructured around a new cleavage between populism and technocracy actually masks a deeper dimension of political opposition - between party democracy and its critics - in terms of which both populism and technocracy find themselves on the same side. This implies that if we accept the idea that politics is increasingly structured in terms of this conflict between populism and technocracy, then we find that even the very possibility of articulating a defense of party democracy is excluded from the political spectrum. This, we believe, is something which should be both of practical concern and of interest to those scholars within the field of political theory who have been instrumental in drawing our attention back towards political parties and their role within democratic political life. 


\section{REFERENCES}

Albertazzi, Daniele and McDonnell, Duncan (2008) Twenty-First Century Populism: The Specter of Western European Democracy, London: Palgrave.

Arditi, Benjamin. 2005. 'Populism as an internal periphery of democratic politics' in Panizza, Francisco, Populism and the Mirror of Democracy, London: Verso.

Bader, Veit. 2014. 'Crisis of political parties and representative democracies: rethinking parties in associational, experimentalist governance', in Critical Review of International Social and Political Philosophy, 17: 3.

Bonotti, Matteo. 2014. 'Partisanship and Public Reason' in Critical Review of International Social and Political Philosophy, 17: 3.

Canovan, Margaret. 1981. Populism, New York: Harcourt Brace Jovanovich.

--- 1999. 'Trust the People! Populism and the Two Faces of Democracy', Political Studies 47:1.

Duverger, Maurice. 1954. Political Parties. Their Organization and Activity in the Modern State, New York: Wiley.

Ferrara, Alessandro. 2008. The Force of the Example: Explorations in the Paradigm of Judgmement, New York: Columbia University Press.

Fischer, Frank. 2009. Democracy and Expertise. Oxford: Oxford University Press.

Freeland, Chrystia. 2010. "Forget left and Right. The real divide is technocrats versus populists", Reuters. Full text available at: http://blogs.reuters.com/chrystiafreeland/2010/11/05/forget-left-and-right-the-real-divide-is-technocrats-versus-populists/

Fukuyama, Francis. 2014. Political Order and Political Decay. From the Industrial Revolution to the Globalization of Democracy. New York: Farrar, Straus and Giroux.

Gellner, Ernest and Ionescu, Ghita. 1969. Populism: Its Meaning and National Characteristics, New York: Macmillan.

Goodin, Robert. 2008. Innovating Democracy. Oxford: Oxford University Press.

Grillo, Beppe; Casaleggio, Gianroberto. 2011. Siamo in Guerra. Per una nuova politica. Milano: Chiarelettere.

Goulard, Sylvie and Monti, Mario. 2012. De la Démocratie en Europe. Voir Plus Loin, Paris: Flammarion. 
Hofstadter, Richard. 1969. The Idea of a Party System. The Rise of Legitimate Opposition in the United States, 1780-1840. Los Angeles: University of California Press.

Iglesias Pablo; Rivero Jacobo. 2014. Conversacion con Pablo Iglesias, Madrid: Turpial.

Katz, Richard S. and Mair, Peter. 1995. "Changing Models of Party Organization and Party Democracy", Party Politics, 1:1.

Kenneally, Ivan. 2009. “Technocracy and Populism”, The New Atlantis, Spring.

Kelsen, Hans. The Essence and Value of Democracy, Lanham: Rowman and Littlefield, 2013.

Kircheimer, Otto. 1969. 'The Transformation of Western European Party Systems' in Joseph LaPalombara and Myron Weiner, Political Parties and Political Development, Princeton:

Princeton University Press.

Laclau, Ernesto. 2005a. On Populist Reason, London: Verso.

--- 2008. "Populism: What's in a Name?" in Panizza, Populism and the Mirror of

Democracy, London: Verso.

Laclau, Ernesto; Mouffe, Chantal. 1985. Hegemony and Socialist Strategy. Towards a Radical Democratic Politics. London: Verso.

Leonard, Mark. 2011. "Four Scenarios for the Reinvention of Europe", EFCR, London. Full text available at: http://www.ecfr.eu/page/-

/ECFR43_REINVENTION_OF_EUROPE_ESSAY_AW1.pdf

LePen, Marine. 2012. Pour que vive la France, Paris: Grancher-.

Lipset, Seymour Martin and Rokkan, Stein. 1967. Party systems and voter alignments: crossnational perspectives, New York: Free Press.

Maier, Charles. 1981. 'Fictitious Bonds...of Wealth and Law: On the Theory and Practice of Interest Representation', in S. Berger, eds., Organizing Interests in Western Europe, New York: Cambridge University Press.

Mair, Peter. 2014. On Parties, Party Systems and Democracy. Essex: ECPR Press.

Manin, Bernard. 1997. The Principles of Representative Government. Cambridge: Cambridge University Press.

McDonnell, Duncan and Valbruzzi, Marco. 2013. "Defining and Classifying Technocrat-led and Technocratic Governments", paper presented at the European Union Studies Association Conference, 9-11 May, Baltimore.

Majone, Giandomenico, 1996. Regulating Europe, London: Routledge. 
--- 2005, Dilemmas of European Integration: The Ambiguities and Pitfalls of Integration by Stealth. Oxford: Oxford University Press.

Melenchon, Jean-Luc. 2014. L'ère du peuple. Paris: Fayard.

Mudde, Cas. 2004. “The Populist Zeitgeist”, Government and Opposition, 39:4.

Muller, Jan-Werner. 2013. 'We the People. On Populism and Democracy', lecture delievered at the Institute for Human Sciences of the University of Vienna, available at: http://www.iwm.at/events/event/iwm-lecture-in-human-sciences-we-the-people-on-populismand-democracy-i/

Muirhead, Russell; Rosenblum, Nancy. 2006. 'A Defence of Party Spirit', Perspectives on Politics, 4 (4).

Offe, Claus. 2013. 'Europe Entrapped', Modern Law Review, 19(5) pp595-611

Pitkin, Hannah. 1967. The Concept of Representation. Berkeley: University of California Press.

Rosanvallon, Pierre. 2008. Counter-Democracy. Politics in an Age of Distrust. Cambridge: Cambridge University Press.

2011. Democratic Legitimacy. Impartiality. Reflexivity. Proximity. Princeton: Princeton University Press.

Rosenblum, Nancy. 2008. On the Side of the Angels. An Appreciation of Parties and Partisanship. Princeton: Princeton University Press.

Sartori, Giovanni. 1976. Parties and Party Systems. A Framework for Analysis. Cambridge: Cambridge University Press.

Saward, Michael. 2010. The Representative Claim. Oxford: Oxford University Press.

Scharpf, Fritz. 1999. Governing Europe: Effective and Democratic? Oxford: Oxford University Press.

Schattschneider, Eric. 1942. Party Government. New York: Praeger.

Schmidt, Vivienne. 2006. Democracy in Europe: The EU and National Polities, Oxford: Oxford University Press.

--- 2011. “Can Technocratic Government Be Democratic?", Telos, 23.

Schmitt, Carl. 1921. The Concept of the Political. Chicago: University of Chicago Press, 2007. --- 1923. The Crisis of Parliamentary Democracy. Chicago: University of Chicago Press, 2008.

Taggart, Paul. 2000. Populism, New York: Open University Press. 
Urbinati, Nadia. 2014. Democracy Disfigured, Cambridge: Harvard University Press.

White, Jonathan; Ypi, Lea. 2010. 'Rethinking the Modern Prince: Partisanship and the Democratic Ethos', in Political Studies, 58:1.

White, Jonathan. 2014. 'Transnational Partisanship. Idea and Practice' in Critical Review of International Social and Political Philosophy, 17: 3.

Williams, Conor. 2011. 'Technocracy and Populism', Dissent Magazine, October $22^{\text {nd }}$ (available at: www.dissentmagazine.org/online_articles/technocracy-and-populism). 